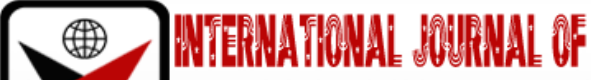

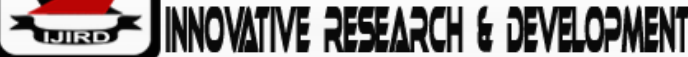

ISSN 2278-0211 (Online)

\section{Environmental Quality Perception of Lecture Halls and Effect on Students' Satisfaction in Akwalbom State, Nigeria}

\author{
Aniefiok 0.Akpan \\ Senior Lecturer, Department of Physics, AkwaIbom State University, Nigeria
}

\begin{abstract}
:
This paper examines the general satisfaction of University students in AkwaIbom State with the acoustic, daylight and air qualities of their lecture halls. Ambient noise levels of 65.85, 68.95 and 61.67 dB(A) were recorded around the surveyed schools' environment with a sound level meter and were found to be below the recommended level of $70 \mathrm{~dB}(A)$ which of course was an advantage to the comfort ability of the students while in their lecture halls. The ambient noise possesses no threat to the satisfaction of the students when considering acoustic parameters such as speech intelligibility, speech perception, speech quality and signal to noise ratio (SNR) hence the high rating of the lecture halls by the students. A total of 1200 (one thousand two hundred) questionnaires were equally distributed to both male and female students (respondents) in the three tertiary institutions under study, out of which 1002 (one thousand and two) representing 83.5\% responses were received. Rank correlation of the responses showed 97.5\% correlation between AkwaIbom State University and University of Uyo, 99.7\% between AkwaIbom State University and Obong University and 98.4\% correlation between Obong University and University of Uyo. Averagely a very high correlation of $98.5 \%$ obtained showed an agreed perception of these qualities among the students. Chi-square test upholds the hypothesis by $92.2 \%$ of the respondents that they are generally satisfied with their lecture halls as opposed to the alternative hypothesis by $7.8 \%$ of the respondents. Chi- square tabulated at $5 \%$ probability obtained from chi-square value under 2 (degree of freedom) was 5.99. Chi- square calculated which was 3.4707 is less than the tabulated (5.99) which affirms the assertion by the respondents that they are generally satisfied with their lecture halls. It is therefore concluded from this analysis that the lecture halls in the surveyed schools are of high quality when considering their environmental qualities (acoustic, daylight and air qualities) and the students are generally satisfied.
\end{abstract}

Keywords: Environmental quality, acoustic quality, daylight quality, air quality, students' satisfaction, lecture halls

\section{Introduction}

The challenge in studying environmental qualities such as acoustic, daylight and air qualities of lecture halls in schools may be affected by factors like building location, city or building design (Camara et al 2018). Until the nineteenth century, the acoustic design of halls and churches was largely an art practiced by architects and engineers.

Lecture halls in Universities are occupied by students and lecturers for lectures but the acoustic design of are neglected thereby getting students distracted. The benefits of good architectural acoustics design to students include increase in productivity, improved health, good perception of surrounding activities in terms of their satisfaction and preference, good logical thinking, (better attention and alertness to surrounding activities and high motivation to work. Sound in lecture halls that gets into the ear of students are both direct and reflected sound, it has to be clear enough when listening to It (Tang S. K. et al, (2006).

The usefulness of light for clear vision cannot be over emphasised. Light from ordinary source like the sun or light bulbs radiate away from the source in all directions and the spreading or divergence of this ordinary light is what makes it so useful in lighting lecture halls in schools, homes and work places. A well illuminated lecture hall is very necessary for students to have a clear vision of their daily academic activities while in class and also for their comfort (Seeber, 1992). Lighting in an environment is one of the necessary and important elements which have direct impact on peoples' performance, students are no exception. Apart from all indoor (artificial) light profits, natural light has more benefit on people's health and wellbeing. Having apt windows in lecture halls are very important for having appropriate daylight for viewing. This connection from outside can provide significant physical and physiological benefits for users especially students (Sanaz, 2020).

Effective daylight is an important modern educational architecture. Research has shown that quality natural light can have a notable impact on students' attainment. A study of over 21000 US students in 1999 showed that those with most daylight in their classrooms progressed 20\% faster in Mathematic test and 26\% faster in reading test than those with 
least. A further study of 71 elementary schools provided additional evidence that good lighting provided from both natural and artificial sources significantly influenced pupils' reading vocabulary. (Lee, 2011)

Schools' physical environment according to recent research can play a major role in academic performance of students and pupils. Poor physical environment due to leaky roofs, problems of heating, ventilation and air conditioning (HVAC), insufficient cleaning and other maintenance issues can trigger a lot of health problems including asthma and allergies that can increase absenteeism thereby reducing academic performance. Improvement in school environmental quality can enhance academic performance as well as teacher and staff productivity (Khaleghi et al 2011)

Learning in an air polluted environment can affect students' performance. A study on the scholastic performance of students in standardized examination in Israel found that taking exams in a polluted day was associated with a 3.2\% decline in students' test score. Those students who sat exams highly polluted days had a lower chance of at university compared with their unaffected counterparts.Short- term exposure to as little as an additional 10 unit of $\mathrm{PM}_{2.5}$ (air quality index) during the matriculation examination is associated with a $2.1 \%$ decline in monthly earnings in adulthood. (Lavy and Roth, 2014). It has also been found that air pollution has a negative impact on the cognitive ability including forgetfulness, inattentiveness and careless errors (Sunyer et al, 2017).

Study on the effect of steel mill opening and closing in Utah valley in US showed that an increase of 100 micrograms of $\mathrm{PM}_{10}$ increased school absence by $40 \%$ (Currie et al, 2009).

\section{Statement of the Problem}

Environmental conditions of lecture halls have been seen to have significant influence on the academic performance of students and is one of the causes of decline performance of teachers or lecturers (Sant'Anna et al, 2018). Poor environmental quality can reduce academic performance as well as teacher and staff productivity. Students may experience difficulties on learning and social interaction as well as having greater time lost to disruptive activities during lessons due to poor acoustics.

This work examines the general satisfaction of universitystudents in Akwalbom State with the environmental quality (acoustic, daylight and air qualities) of their lecture halls.

\section{Methodology}

Three tertiary institutions were selected for this study namely AkwaIbom state University owned by the State Government, University of Uyo owned by the Federal Government and Obong University, a private institution. They are all situated in AkwaIbom State, South-South Nigeria. The environmental qualities considered were acoustic, air, daylight and experience of potential problems from ambient noise levels from air, music, voices (outdoor noise), noise from highway traffic and ventilation systems on the satisfaction of the respondents with the acoustic environment of the lecture halls. The data collected were geared towards testing the relationship between perceived IEQ and the general satisfaction of the respondents.

\subsection{About Akwalbom State}

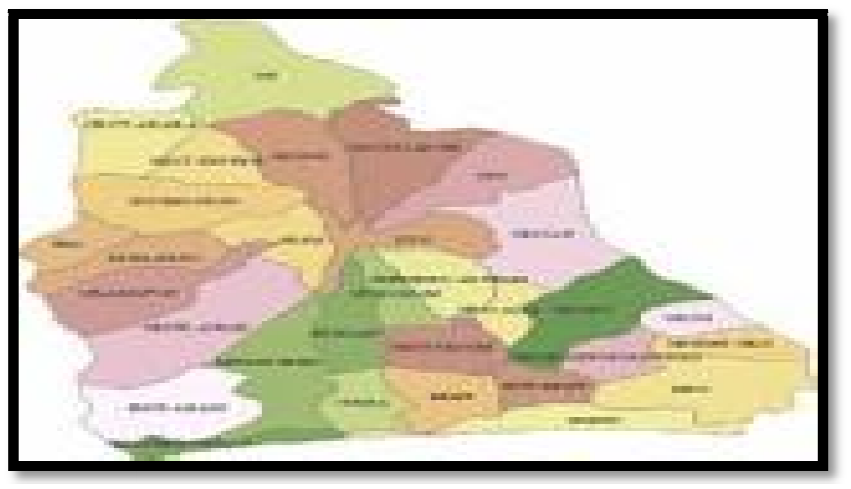

Figure1: Map of Akwalbom State, Nigeria

AkwaIbom is astateinNigeria. It is located in the coastal southern part of the country, lying between latitudes $4^{\circ} 32^{\prime} \mathrm{N}$ and $5^{\circ} 33^{\prime} \mathrm{N}$, and longitudes $7^{\circ} 25^{\prime} \mathrm{E}$ and $8^{\circ} 25^{\prime} \mathrm{E}$. The state is located in the South-South geopolitical zone, and is bordered on the east by Cross River State, on the west by Rivers StateandAbia State, and on the south by the Atlantic Ocean and the southernmost tip of Cross River State.

It is one of Nigeria's 36 states, with a population of over five million people in 2016. The state was created on September 23,1987, and is currently the highest oil- and gas-producing state in the country. The state's capital isUyo, with over 500,000 inhabitants. The State for now has University of Uyo owned by the Federal Government,AkwaIbom State University owned by the State Government and three private universities namely Obong University, Ritman University and Top Faith University.

\subsection{Data Collection}

Questionnaire with well structured, simple and closed questions was developed for this study with the aim of collecting the respondents' perception of indoor environment quality (IEQ) of the lecture halls and their general 
satisfaction. The respondents were drawn from male and female students of these institutions and were believed to have been 18 years and above since this the official age that qualifies one to be admitted for studies in Nigerian Universities.

Sound level meter Bruel and kjaer (B\&K) type 2203 and its associated octave band filter (B\&K) type 2203 was used to measure the ambient noise levels so as to ascertain the relationship between objective assessment of the environment and the respondents' subjective ratings. Measurements with the sound level meter were done with the meter set at A-weighted slow response and at a height of $1.5 \mathrm{~m}$ above the ground being an average hearing position.

Quantitative analysis of data using Chi-square was carried out to test the respondent's assertion on the general satisfaction of their lecture halls.

$X_{c}^{2}=\sum \frac{\left(0_{i}-E_{i}\right)^{2}}{E_{i}}$

Where $\quad \mathrm{X}^{2}{ }_{\mathrm{c}} \quad=\quad$ Calculated chi-square

$\mathrm{O}_{\mathrm{i}} \quad=\quad$ Observed frequency

$\mathrm{E}_{\mathrm{i}} \quad=\quad$ Expected frequency

$\mathrm{x}_{\mathrm{t}}=\operatorname{alpha}(r-1)(c-1)$

Where $\quad \mathrm{X}^{2}{ }_{\mathrm{t}}=\quad$ Chi-square tabulated

$\mathrm{r} \quad=\quad$ Number of rows

$\mathrm{c} \quad=\quad$ Number of columns

Alpha taken at $5 \%$ probability

The perceived qualities were rated very good (5), good (4), fair (3), poor (2) or very poor (1) by the respondents.Rank correlation coefficient was used to test how correlated the respondents' rantings of perceived qualities of their lecture halls were.

$r=1-\frac{6 \sum D^{2}}{N^{3}-N}$

Where $\mathrm{r} \quad=$

$\begin{array}{ll}\mathrm{D} & = \\ \mathrm{N} & = \\ \Sigma & =\end{array}$

Coefficient of rank correlation

Difference between paired ranks

Number of pairs

Summation

\section{Results}

A total of 1200 (one thousand two hundred) questionnaires were equally distributed to both male and female students (respondents) in the three tertiary institutions under study, out of which 1002 (one thousand and two) responses were received as shown in table 1.0

\begin{tabular}{|c|c|c|c|c|}
\hline Institution & Code & $\begin{array}{c}\text { Questionnaires } \\
\text { Sent Out }\end{array}$ & $\begin{array}{c}\text { Questionnaires } \\
\text { Received }\end{array}$ & $\begin{array}{c}\text { Percentage } \\
\text { Response }\end{array}$ \\
\hline Akwalbom State University & $\mathrm{X}$ & 400 & 365 & 91.3 \\
\hline University of Uyo & $\mathrm{Y}$ & 400 & 342 & 85.5 \\
\hline Obong University & $\mathrm{Z}$ & 400 & 295 & 73.8 \\
\hline Total & & 1200 & 1002 & 83.5 \\
\hline
\end{tabular}

Table 1: Rate of Response

\begin{tabular}{|c|c|}
\hline Institution & Average Ambient Noise Levels Db(A) \\
\hline $\mathrm{X}$ & 65.85 \\
\hline $\mathrm{Y}$ & 68.05 \\
\hline $\mathrm{Z}$ & 61.67 \\
\hline
\end{tabular}

Table 2: Average Ambient Noise Levels (dB (A))

\begin{tabular}{|c|c|c|c|c|c|c|c|c|}
\hline \multirow[t]{2}{*}{ Institutions } & \multicolumn{5}{|c|}{ Acoustic Quality Perceived Rating } & \multirow{2}{*}{$\begin{array}{l}\text { Response } \\
\text { per } \\
\text { Institution } \\
\text { (n) } \\
\end{array}$} & \multirow{2}{*}{$\begin{array}{l}\text { Weighting } \\
\text { Rating (nr) }\end{array}$} & \multirow{2}{*}{$\begin{array}{c}\text { Average per } \\
\text { Institution } \\
\text { (nr/n) }\end{array}$} \\
\hline & $\begin{array}{l}\text { Very } \\
\text { Good }\end{array}$ & Good & Fair & Poor & $\begin{array}{l}\text { Very } \\
\text { Poor }\end{array}$ & & & \\
\hline & 5 & 4 & 3 & 2 & 1 & & & \\
\hline $\mathrm{X}$ & 102 & 162 & 96 & 5 & 0 & 365 & 1456 & 4.0 \\
\hline $\mathrm{Y}$ & 98 & 153 & 84 & 7 & 0 & 342 & 1368 & 4.0 \\
\hline $\mathrm{Z}$ & 84 & 137 & 71 & 3 & 0 & 295 & 1187 & 4.02 \\
\hline & & & & & & $\Sigma \mathrm{r}=1002$ & $\Sigma(n r)=4011$ & $\Sigma(\mathrm{nr} / \mathrm{n})=12.2$ \\
\hline
\end{tabular}

Table 3: Overall Acoustic Quality Perception Rating of Lecture Halls 


\begin{tabular}{|c|c|c|c|c|c|c|c|c|}
\hline Institutions & \multicolumn{9}{|c|}{ Daylight Quality Perceived Rating } & $\begin{array}{c}\text { Response } \\
\text { per } \\
\text { Institution } \\
\text { (n) }\end{array}$ & $\begin{array}{c}\text { Weighting } \\
\text { Rating } \\
\text { (nr) }\end{array}$ & $\begin{array}{c}\text { Average } \\
\text { per } \\
\text { Institution } \\
\text { (nr/n) }\end{array}$ \\
\hline & $\begin{array}{c}\text { Very } \\
\text { good }\end{array}$ & Good & Fair & Poor & $\begin{array}{c}\text { Very } \\
\text { poor }\end{array}$ & & & \\
\hline & $\mathbf{5}$ & $\mathbf{4}$ & $\mathbf{3}$ & $\mathbf{2}$ & $\mathbf{1}$ & & & \\
\hline $\mathrm{X}$ & 205 & 104 & 56 & 0 & 0 & 365 & 1609 & 4.41 \\
\hline $\mathrm{Y}$ & 209 & 127 & 5 & 1 & 0 & 342 & 1570 & 4.60 \\
\hline $\mathrm{Z}$ & 191 & 101 & 3 & 0 & 0 & 295 & 1368 & 4.61 \\
\hline & & & & & & $\Sigma \mathrm{r}=1002$ & $\begin{array}{c}\Sigma(\mathrm{nr})= \\
4547\end{array}$ & $\begin{array}{c}\Sigma(\mathrm{nr} / \mathrm{n})= \\
13.62\end{array}$ \\
\hline
\end{tabular}

Table 4: Overall Daylight Perception Rating of Lecture Halls by the Respondents

\begin{tabular}{|c|c|c|c|c|c|c|c|c|}
\hline Institutions & \multicolumn{5}{|c|}{ Air Quality Perceived Rating } & $\begin{array}{c}\text { Response } \\
\text { per } \\
\text { Institution } \\
\text { (n) }\end{array}$ & $\begin{array}{c}\text { Weighting } \\
\text { Rating } \\
\text { (nr) }\end{array}$ & $\begin{array}{c}\text { Average } \\
\text { per } \\
\text { Institution } \\
\text { (nr/n) }\end{array}$ \\
\hline & $\begin{array}{c}\text { Very } \\
\text { Good }\end{array}$ & Good & Fair & Poor & $\begin{array}{c}\text { Very } \\
\text { Poor }\end{array}$ & & & \\
\hline & $\mathbf{5}$ & $\mathbf{4}$ & $\mathbf{3}$ & $\mathbf{2}$ & $\mathbf{1}$ & & & \\
\hline $\mathrm{X}$ & 195 & 151 & 17 & 2 & 0 & 365 & 1634 & 4.48 \\
\hline $\mathrm{Y}$ & 138 & 201 & 3 & 0 & 0 & 342 & 1506 & 4.40 \\
\hline $\mathrm{Z}$ & 201 & 87 & 5 & 2 & 0 & 295 & 1372 & 4.65 \\
\hline & & & & & & $\Sigma \mathrm{r}=1002$ & $\begin{array}{c}\Sigma(\mathrm{nr})= \\
4512\end{array}$ & $\begin{array}{c}\Sigma(\mathrm{nr} / \mathrm{n})= \\
13.53\end{array}$ \\
\hline
\end{tabular}

Table 5: Overall Air Quality Perception Rating in Lecture Halls by the Respondents

\begin{tabular}{|c|c|c|c|c|c|c|}
\hline \multirow[t]{2}{*}{ Perceived Qualities } & \multicolumn{2}{|c|}{$\begin{array}{c}\text { Average Rating Per } \\
\text { Institution }\end{array}$} & \multirow[t]{2}{*}{ D } & \multirow[t]{2}{*}{$\overline{\mathbf{D}^{2}}$} & $\mathbf{R}$ & $\% \mathrm{r}$ \\
\hline & $\mathrm{X}$ & $\mathrm{Y}$ & & & \multirow{5}{*}{0.975} & \multirow{5}{*}{97.5} \\
\hline Acoustic quality & 4.0 & 4.0 & 0 & 0 & & \\
\hline Daylight quality & 4.41 & 4.60 & -0.19 & 0.036 & & \\
\hline \multirow{2}{*}{ Air quality } & 4.48 & 4.40 & 0.08 & 0.064 & & \\
\hline & & & $\Sigma \mathrm{D}^{2}=0.1$ & & & \\
\hline \multirow[t]{2}{*}{ Perceived Qualities } & \multicolumn{2}{|c|}{$\begin{array}{c}\text { Average Rating Per } \\
\text { Institution }\end{array}$} & $\mathrm{D}$ & $\mathrm{D}^{2}$ & $\mathrm{r}$ & $\% \mathrm{r}$ \\
\hline & $\mathrm{X}$ & $\mathrm{Z}$ & & & \multirow{5}{*}{0.997} & \multirow{5}{*}{99.7} \\
\hline Acoustic quality & 4.0 & 4.02 & -0.02 & 0.0004 & & \\
\hline Daylight quality & 4.41 & 4.61 & -0.20 & 0.04 & & \\
\hline \multirow[t]{2}{*}{ Air quality } & 4.48 & 4.45 & -0.17 & 0.029 & & \\
\hline & & & & $\begin{array}{c}\Sigma \mathrm{D}^{2}= \\
0.0694\end{array}$ & & \\
\hline \multirow[t]{2}{*}{ Perceived Qualities } & \multicolumn{2}{|c|}{$\begin{array}{c}\text { Average Rating Per } \\
\text { Institution }\end{array}$} & $\mathrm{D}$ & $\mathrm{D}^{2}$ & $\mathrm{r}$ & $\% \mathrm{r}$ \\
\hline & $\mathrm{Z}$ & $\mathrm{Y}$ & & & \multirow{5}{*}{0.984} & \multirow{5}{*}{98.4} \\
\hline Acoustic quality & 4.02 & 4.00 & 0.02 & 0.0004 & & \\
\hline Daylight quality & 4.61 & 4.60 & 0.10 & 0.0001 & & \\
\hline Air quality & 4.65 & 4.40 & 0.25 & 0.063 & & \\
\hline & & & & $\begin{array}{l}\Sigma D^{2}= \\
0.064\end{array}$ & & \\
\hline
\end{tabular}

Table 6: Correlation Analysis of the Perceived Quality Ratings Using Rank Correlation Coefficient Average correlation on perceived quality rating from respondents in the three institution $=98.5 \%$

\begin{tabular}{|c|c|c|c|c|}
\hline Response & X & Y & Z & Total \\
\hline A YES & 341 & 304 & 279 & 924 \\
\hline B NO & 24 & 38 & 16 & 78 \\
\hline Total & 365 & 342 & 295 & 1002 \\
\hline
\end{tabular}

Table 7: Overall Response On General Satisfaction with the Lecture Halls 


\begin{tabular}{|c|c|c|c|c|c|}
\hline Responses & $\mathbf{O}_{\mathbf{i}}$ & $\mathbf{E}_{\mathbf{i}}$ & $\mathbf{O}_{\mathbf{i}}-\mathbf{E}_{\mathbf{i}}$ & $\left(\mathbf{O}_{\mathbf{i}}-\mathbf{E}_{\mathbf{i}}\right)^{\mathbf{2}}$ & $\left(\mathbf{O}_{\mathbf{i}}-\mathbf{E}_{\mathbf{i}}\right)^{\mathbf{2}} / \mathbf{E}_{\mathbf{i}}$ \\
\hline $\mathrm{AX}$ & 341 & 336.6 & 4.4 & 19.36 & 0.0575 \\
\hline $\mathrm{AY}$ & 304 & 315.4 & -11.4 & 13.0 & 0.0412 \\
\hline $\mathrm{AZ}$ & 279 & 272.0 & -4.4 & 19.36 & 0.0712 \\
\hline $\mathrm{BX}$ & 24 & 28.4 & -4.4 & 19.36 & 0.6817 \\
\hline $\mathrm{BY}$ & 38 & 26.6 & 11.4 & 13.0 & 0.4887 \\
\hline $\mathrm{BZ}$ & 16 & 23.0 & -7.0 & 49 & 2.1304 \\
\hline
\end{tabular}

Table 8: Chi-Square Analysis of Response Data on General Satisfaction

Calculated $\mathrm{X}_{\mathrm{c}}{ }_{\mathrm{c}}$ (chi-square $)=3.4707$

$\mathrm{X}^{2}$ tabulated

$$
\begin{array}{lll}
= & \mathrm{X}^{2}{ }_{\mathrm{t}} 0.05(2-1)(3-1) \\
= & \mathrm{X}^{2}{ }_{\mathrm{t}} 0.05(1)(2) \\
= & \mathrm{X}^{2}{ }_{\mathrm{t}} 0.05(2) \\
= & 5.99
\end{array}
$$

Chi- square tabulated at 5\% probability obtained from chi-square value under 2 (degree of freedom) is 5.99. Chisquare calculated which was 3.4707 is less than the tabulated(5.99) which affirms the assertion by the respondents that they are generally satisfied with their lecture halls.

\section{Discussion of Results}

Table 1.0 shows that an average of $83.5 \%$ of the questionnaires shared to respondents were responded to. This is a very high response indicating that a greater number of the students in tertiary institutions in Akwalbom State have interest in research of this nature.

Ambient noise is the total noise associated with a given environment and usually comprises of sounds from many sources both far and near. Table 2.0 shows ambient noise levels of 65.85,68.95 and $61.67 \mathrm{~dB}(\mathrm{~A})$ in AkwaIbom State University, University of Uyo and Obong University lecture room environments respectively. The recommended ambient noise level which should not be exceeded even during the noisiest hour of the day around schools etc is $70 \mathrm{~dB}(\mathrm{~A})$ according to the noise level standard issued by the Federal Highway Administration Policy and Procedure Memorandum (PPM) 90-2. If higher than this may provide a masking effect on the sounds that the listener is trying to hear. The ambient noise around these study areas which are even below the recommended standard of $70 \mathrm{~dB}(\mathrm{~A})$ therefore possess no threat to the satisfaction of the respondents when considering acoustic parameters such as speech intelligibility, speech perception, speech quality and signal to noise ratio (SNR). With these levels of ambient noise, the student will have no difficulty in learning and social interaction with their colleagues and lecturers. Neither will they have great time loss to disruptive activities during lectures. This agrees with the answers given by $92.2 \%$ of the respondents (Table 7.0 ) that they are generally satisfied with their lecture halls.

Tables 3, 4, 5 show a high rating of the lecture halls by the respondents when considering the acoustic, daylight and air qualities of these lecture halls. It was necessary to correlate the respondents' responses on these ratings since they were from three different institutions situated at different environments and locations and the respondents acted independently. Rank correlation of the responses showed 97.5\% correlation between AkwaIbom State University and University of Uyo (Table 6.0 a) ,99.7\% between AkwaIbom State University and Obong University (Table 6.0 b) and 98.4\% correlation between Obong University and University of Uyo (Table 6,0 c). Averagely a very high correlation of 98.5\% obtained showed an agreed perception among the respondents.

Chi-square test (Table 8.0) upholds the hypothesis by $92.2 \%$ of the respondents that they are generally satisfied with their lecture halls as opposed to the alternative hypothesis by $7.8 \%$ of the respondents. It is recommended that the physiological status of these smaller numbers of respondents be tested.

\section{Conclusion}

It is therefore concluded from this analysis that the lecture halls in the surveyed schools are of high quality when considering their acoustic, daylight and air qualities and the students are generally satisfied.

\section{Acknowledgement}

We sincerely thank all the respondents that showed interest in this research by answering the questions and turning in the questionnaires given to them.

\section{References}

i. About AkwaIbom | AkwaIbom State'. Retrieved 2021-09-10.

ii. Abbaszadeh, S. et al (2006): Occupants Satisfaction with Indoor Environmental Quality in Green Buildings. In Proceedings of the eighth International Conference for Healthy Buildings. Creating a Healthy Indoor Environment for People, Lisborn, Portugal.

iii. Camara et al. (2018): Management of Acoustic Risk for Buildings Near Airport. Ecol. Inform., 44, 43-56

iv. Curie et al (2009): Does Pollution Increase School absence? Rev. Econ. Stat, 91, 682-694.

v. Curie et al (2014): What do we know about short- and long-term Effects of Early Life Exposure to Pollution? Annu. Rev. Resourc. Econ. 6, 217-247

vi. 'High Way Noise. A design Guide for Highway Engineers': (1971): Cooperative Highway Research Program Report 117. Highway Research Board, National Academy of Science- National Academy of Engineering. 
vii. Khaleghi, A. et al (2011): Factors Affecting Ventilation, Indoor air Quality and Acoustical Quality in Green and Non Green Building. A Pilot Study. J. Green Buildings, 6, 168-180

viii. Lavy V. and Roth S. (2014): The impact of short Exposure to Ambient Air Pollution on Cognitive Performance and Human Capital Formation. Natl. Bur. Econ. Res. 1-40

ix. Sant'Anna, D. O. et al (2018): Indoor Environmental Quality Perception and Users' satisfaction of conventional and Green Buildings in Brazil. Sustain. Cities Soc. 43, 95-110

x. 10 Sanaz et al (2020): Impact of Daylight on Students' Learning: A review paper, Payane Noor University.

xi. Seeber, F. P. (1992): Laser Practices and Problems in Educational Institutions. Proceedings, International Laser safety Conference, Cincinnati, Ohio.

xii. Schultz, T. (1971): Diffusion in Reverberation Rooms. Journal of Sound and Vibration. 16, 17 - 28.

xiii. Sunyer et al (2017): Traffic Related air Pollution and Attention in Primary School Children. Epidemiology 28, 181-189

xiv. Tang S. K. and Yeung, M. H. (2006): Reverberation Time and Speech Transmission Indices in Classrooms. Journal of Sound and Vibration. 294, $596-607$.

xv. 15Lee, Y. S (2011): Lighting Quality in LEED Certified Buildings Using Occupant Evaluation J. Green Buildings, 6, 139-155.

xvi. 16 World Health Organisation (2018): Ambient (outdoor) Air Quality and Health. www.who.int/news.

xvii. Zalsjska- Johnson, A. and Wilhelmsson, M. (2013): Impact of Perceived Indoor Environmental Quality on Overall Satisfaction in Swedish dwellings. Building Environment, 63, 134-144.

\section{Questionnaire}

\section{Appendix}

Dear Respondent

This questionnaire is intended to be used to accumulate data for research on the environmental quality of lecture halls in our tertiary institutions. Please help us by supplying the information. It will be treated with the strictest confident.

Researcher

\section{Section A}

1. Name of Institution:

2. Address of Institution:.

3. Date of Interview:.....

4. Time of Interview:

5. Gender: Male Female (tick one)

\section{Section $B$}

$1 \quad$ How do you perceive the acoustic quality of your lecture hall?
A) Very Good
B) Good C) Fair
D) Poor
E) Very Poor

$2 \quad$ How do you perceive the daylight quality of your lecture hall?
B) Very Good
B) Good C) Fair
D) Poor
E) Very Poor

$3 \quad$ How do you perceive the air quality of your lecture hall?
A)
Very Good
B) Good C) Fair
D) Poor
E) Very Poor

$4 \quad$ Are you generally satisfied with your lecture halls when considering the qualities mentioned in questions 1,2 , and $3 ?$

A) YES

5 If no, state the reasons

B) No (tick one) 